\title{
脚筋カによる持続追従運動の解析
}

\section{永田昆* 北本拓** \\ A STUDY OF PURSUIT ENDURANCE MOVEMENTS ON LEG MUSCLE STRENGTH}

\section{A. Nagata and H. Kitamoto}

The purpose of this study is to clarify the function of many pursuit movements on the leg muscle strength. As the means of this experiment, the endurance strength of the under-leg muscle was used and the sitting position was applied. Pursuit movements indicated are to track one target of four kinds waves showing on the oscillograph, which consist of 1) sinus, 2) triangular, 3) rectangular, and 4) sawtooth waves and various frequency ranges $(0.1 \sim 0.9 \mathrm{~Hz})$. The condition of the tracking movements is to maintain the added muscle strength of $1 / 2$ level of maximum strength as long as one can be possible.

To record the effects of the experiment, following items were adopted :1) EMG 2) Heart Rate 3) Target curve 4) Pursuit curve 5) Error values between both curves 6) Phase changes between both curves. These records were analyzed by the method of auto-control theory and following points were obtained.

1. The optimal limit of the wave frequency on the pursuit endurance movement were about $0.5 \mathrm{~Hz}$.

2. The sawtooth wave target was easy and good performance to track the leg muscle strength and had the longest endurance time to maintain also.

3. Near the all-out condition of the pursuit, the amplitude of EMG in the M. Rectus Femoralis and the beats of Heart Rate increased gradually till twice times as the fresh condition but there were no changes of EMG and H.R. according to the variety of wave sorts and frequency.

4. The phase difference between the target and controlled waves was reversed at the fast frequency of $0.7 \mathrm{~Hz}$ more, and under $0.6 \mathrm{~Hz}$, this phase was supported somehow.

5. As the control element of the pursuit movent, the leg muscle effecter showed the high amplified gain in proportion to the endurance time and the high frequency.

(J. Physical Fitness Japan 1974, $23: 134 \sim 143$ )

\section{1. 緒}

手や腕の追従能力に関する研究は, 工学的な分 野13)588) で多くなされているが, 脚の追彷能力に 関する資料は少なく，永田 ${ }^{10)}$ のロード発生装置に よる張力, 弾性抵抗, 粘性抵抗を連続的に下肢に 加え, 脚の前後並進による追従能力の解析がある が脚の持続的追従に関する研究は少ない。特にバ イオメカニックス的にみたあのは皆無に等しく, 運動のシステムアナリスの基礎資料を提示するも のである。
スポーツ場面での競技者の評価は動きを主体に 評価される場合が多く，何かの目標や課題の動き に競技者の動きが合致することが重要な要素であ り試合の勝敗, 記録にも関係してくる。てれは,一 種の予測能力で過去の経験に基づいた運動技術と 屯考えられる。乙れらは多くの練習, 試合等の経 験によって得られるものであり, ベテラン, 試合 巧者の代名詞にも使われている。そのような技術 に関係した能力のなかで，何かの目標を追いかけ る能力を中心に筋力発揮直後, 中間, オールアウ トの 3 期間を中心に追従能力の変化, 特に筋力の

\footnotetext{
* 東京都立大学理学部体育学教室 Tokyo Metropolitan University

** 国学院大学文学部体育研究室 Kokugakuin University
} 


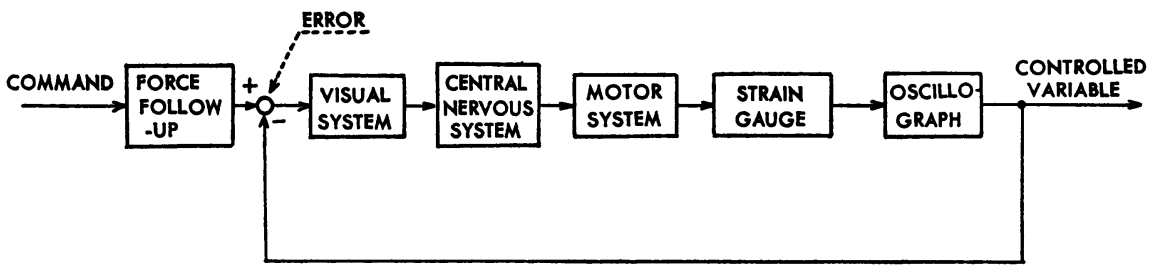

Fig. 1 Block diagram of pursuit movement

発現パターンから検討した。筋力は, 右脚の伸展 運動によって発現させ，膝関節を支点とした円孤 運動をおこなった。

ボール等の運動軌跡を模擬して, 追従させる目 標波形に，4種類のパターンを選び，視覚を主な 情報受容器とし, 足を操作部とし, 大腿直筋, 大 腿二頭筋を主な作動筋として，可能な限り長時間 にわたって追従させた。乙のような，脚の追従持 続春験は、スポーツ，体育の現場にそくしたもの であり，また，運動パターンをシステム的に検討 し得る資料を提共するあのであある。

\section{2. 実 酫 方 法}

追従持続実験をシステム的に把握 するために は，第 1 図のようなブロック線図によって示した 方が解析しやすい，またシステム構成の各要素に 注目し分析することが可能となる。実験姿勢は, 第 2 図のように上体を固定し，足関節のみ可動状 態にしてある。追従運動は, 脚の伸展で被験者は, 体幹を垂直にし，膝関節を $90^{\circ}$ とし測定台上に座

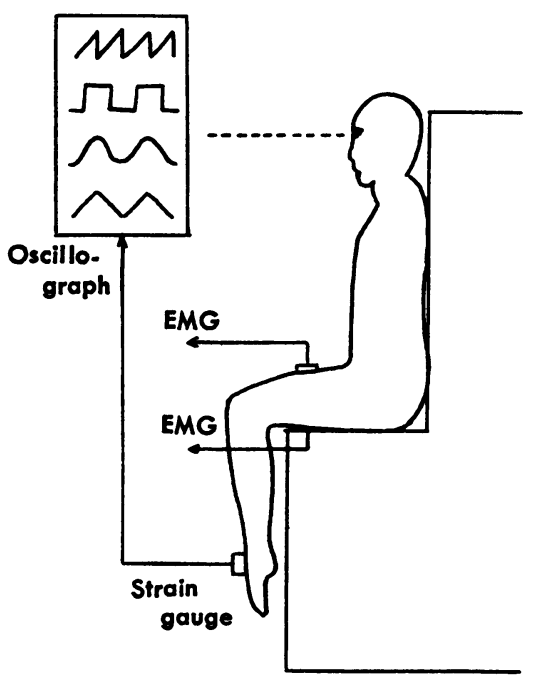

Fig. 2 Experimental posture
り，膝関節を支点とし，足背部を作用点とした。 第 1 図中の情報受容器は, 主に視覚系で, 他に筋 感覚系, レンショウフィードバック路系等がある。 調節部は, 中枢, 脊䯣神経系で, 操作部は, 筋肉 系の下肢, 制御対象は, オッシログラフ上の各種 波形とした。

追従持続力を測定するための実験図が，第 3 図

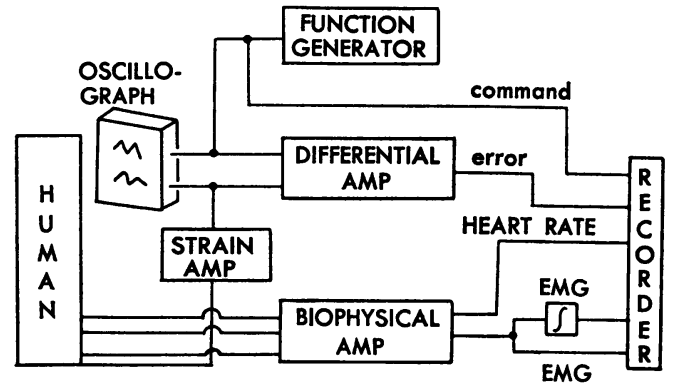

Fig. 3 Block diagram of the experiment

のようで，脚伸展力は，ストレーンゲージ法によ って抽出し, 被験者にフィードバックしオッシロ グラフ紙上にて表示した。目標值として，ファン クションゼネレェーターから発生する各種波形 (1)の乙ぎり波……瞬間的に偏向力を受けるパタ ーンで筋力の増大時になめらかな調節をおこな い, 次に急激な筋力の解放をおこなう運動, (2)矩 形波……指定筋力值を一定に保持するパターン で, 目標筋力值までの筋力の增大および低下の速 応運動, (3)正弦波……筋力值が周期的に変化する パターンで，筋力の増大，低下がゆるやかでなめ らかな調節運動, (4)三角波……定速度で筋力值 が変化しつづけるパターンで, 筋力の増大, 低下が 速度と比例的な運動) を選び, それと追従運動量 との偏差を取り出し，その絶対值の 2 乗値，ある いは, 両者の振幅比, 位相おくれを検出して, 追 従運動のなめらかさ, 安定性, 正確性, 速応性等に ついて評価した。さらに脚伸展の主働筋である大 腿直筋や拮抗笳としての大腿二頭筋の筋電図と心 
永田, 北本

Table 1. Endurance time of subjects

$(\mathrm{sec})$

\begin{tabular}{c|c|c|c|c|c}
\hline \multirow{2}{*}{ Sub } & Wz & Sawtooth & Rectangle & Sinus & Triangular \\
\hline \multirow{3}{*}{$\mathrm{A} \cdot \mathrm{N}$} & 0.1 & 172 & 200 & 115 & 130 \\
& 0.3 & 120 & 130 & 60 & 81 \\
& 0.5 & 115 & 102 & 77 & 71 \\
& 0.7 & 91 & 97 & 95 & 91 \\
& 0.9 & 95 & 95 & 74 & 66 \\
\hline & 0.1 & 66 & 115 & 131 & 90 \\
$\mathrm{H} \cdot \mathrm{K}$ & 0.3 & 73 & 73 & 76 & 65 \\
& 0.5 & 70 & 85 & 104 & 71 \\
& 0.7 & 78 & 60 & 81 & 66 \\
& 0.9 & 86 & 116 & 78 & 116 \\
\hline & 0.1 & 67 & 86 & 81 & 69 \\
& 0.3 & 66 & 59 & 59 & 57 \\
$\mathrm{~K} \cdot \mathrm{S}$ & 0.5 & 55 & 39 & 51 & 60 \\
& 0.7 & 60 & 44 & 57 & 59 \\
& 0.9 & 53 & 48 & 48 & 63 \\
\hline
\end{tabular}

Table 2 Subjects

\begin{tabular}{l|c|c|c|c|c|c}
\hline Name & Sex & Age & Height (cm) & Weight (kg) & Leg Strength (kg) & $\begin{array}{c}\text { Length of Lower } \\
\text { Limb (cm) }\end{array}$ \\
\hline A. N. & M & 36 & 165 & 54 & 12 & 40 \\
H. K. & M & 31 & 163 & 55 & 12 & 40 \\
K. S. & M & 24 & 158 & 50 & 10 & 38 \\
\hline
\end{tabular}

$\mathrm{M}$ : Male

拍数の生体反応も同時に測定した。各被験者の最 大筋力の $1 / 4$ を下限值とし， $2 / 4$ を上限值として 波形を作り，各波形の周波数は，0.1，0.3，0.5， $0.7,0.9 \mathrm{~Hz}$ の 5 種類とした。各周波数, 各波形 での追従運動時間は, 第 1 表に示すように最大持 続とし，次の運動までに 10 分間以上の休息を与 え, 回復を待ったのち低周波数から高周波数へ之 順次追従させた。

被験者は, 健康な成人男子 3 名で第 2 表の通り である。

\section{3. 実 験 結 果}

第 3 図の実験測定から得た結果を以下の順でま とめる。（図は 3 人の被験者の典型的な例として 選んだ）

1）追従能力のできばえ…...パーフォーマンス について。

目標値からの偏差絶対值の 2 乘佔をまとめたも

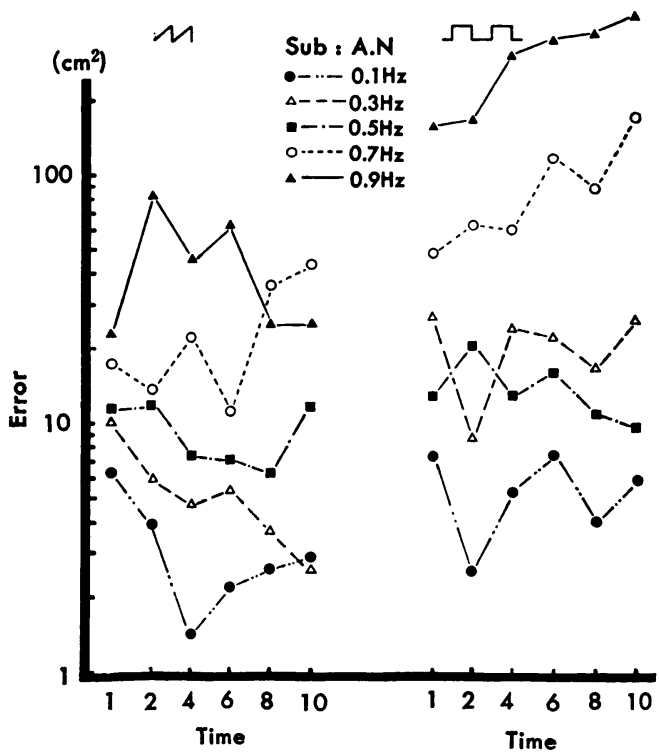

Fig. 4 Changes of performance in the sawtooth and rectangular waves of pursuit movement 


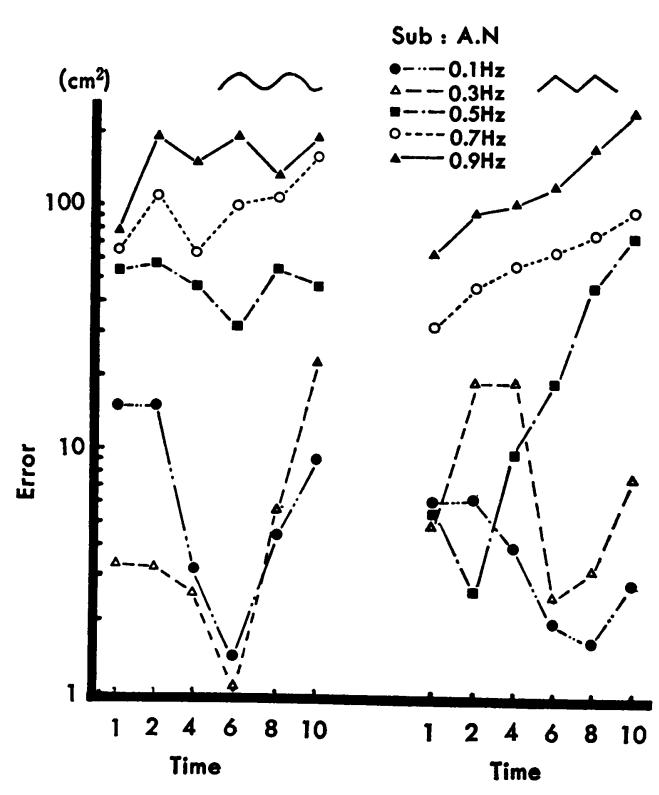

Fig. 5 Changes of performance in the sinus and triangular waves of pursuit movement

のが，第 4 図〜 5 図で，横軸に最大追従持続時間 を10として正規化したものである。この正規化の 理由は, 各被験者, 各周波数, 各波形等でオール アウト時間の絶対値の差をなくすためである。縦 軸には, 偏差の絶対值の 2 乗値をプロットした。

(1) のとぎり波応答では, 周波数が高いほど偏 差量が大きく, $0.1,0.3,0.5 \mathrm{~Hz}$ で運動開始直後 より中期で偏差量が減少し, オールアウト直前で 再び増加し，開始直後の 偏差量と同一になる。 $0.7,0.9 \mathrm{~Hz}$ では, 時間と共に偏差量が増加して いる。

(2) 矩形波応答

$0.3,0.5 \mathrm{~Hz}$ の偏差量は，ほとんど同じく，0.7 $\mathrm{Hz}$ は，0.1，0.3. $0.5 \mathrm{~Hz}$ の約 3 倍，0.9Hzでは， 約10倍の偏差量がみられた。 $0.7,0.9 \mathrm{~Hz}$ では， 時間と共に偏差量に急激な增加がみられた。

(3) 正弦波応答

$0.1,0.3,0.5 \mathrm{~Hz}$ では, 運動の中期で顕著な偏 差量の減少がみられ，オールアウト直前で再び増 加する。0.7, $0.9 \mathrm{~Hz}$ では, 時間と共に比例的に 增加するパターンがみられた。

(4) 三角波応答

$0.1,0.3 \mathrm{~Hz}$ では，運動の中期で顕著な偏差量 の減少がみられ，オールアウト時に近づくと再び

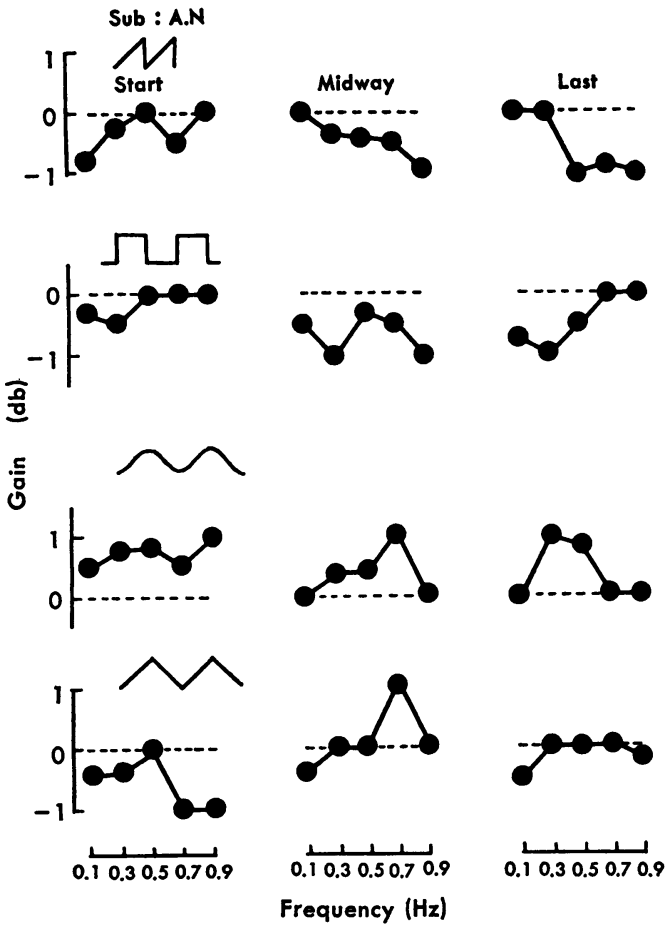

Fig. 6 Changes of amplitude in the case of the pursuit movement

増加する。0.7, $0.9 \mathrm{~Hz}$ では，矩形波応答之同じ ように時間と共に急激な偏差量の 増加がみられ た。

2）追従持続筋力の正確性の変化

第 6 図は，目標波形と追従運動との振幅の差を まとめたもので, 横軸に周波数をとり, 綎軸に振 幅比 $\left(\frac{\text { 操作波形 }}{\text { 目標波形 }}\right)^{11)}$ をプロットした。図中, Start, Midway, Lastは，各被験者が各実験セクション での 最大追従運動時間を 10 とし 正規化したもの で, 運動開始直後 1 3 (30 秒間), 中間 5 7 (30秒間), オールアウト直前 $8 \sim 10$ (30秒間) の それぞれを示す。（以下同様）

(1) のこぎり波応答

$0.1,0.3 \mathrm{~Hz}$ では，目標値の振幅より追従運動 の振幅が小さいが，時間との有意な差はみられな かった。0.5，0.7，0.9Hzでは，運動時間と共に 追従運動の振幅が小さくなることがみられた。

(2) 矩形波応答

$0.1,0.3,0.5 \mathrm{~Hz}$ では, 時間と共に, 追従運動 の振幅が小さくなり，0.7, $0.9 \mathrm{~Hz}$ では，運動の 中期で 目標波形より追従運動の 方が 小さくなる 


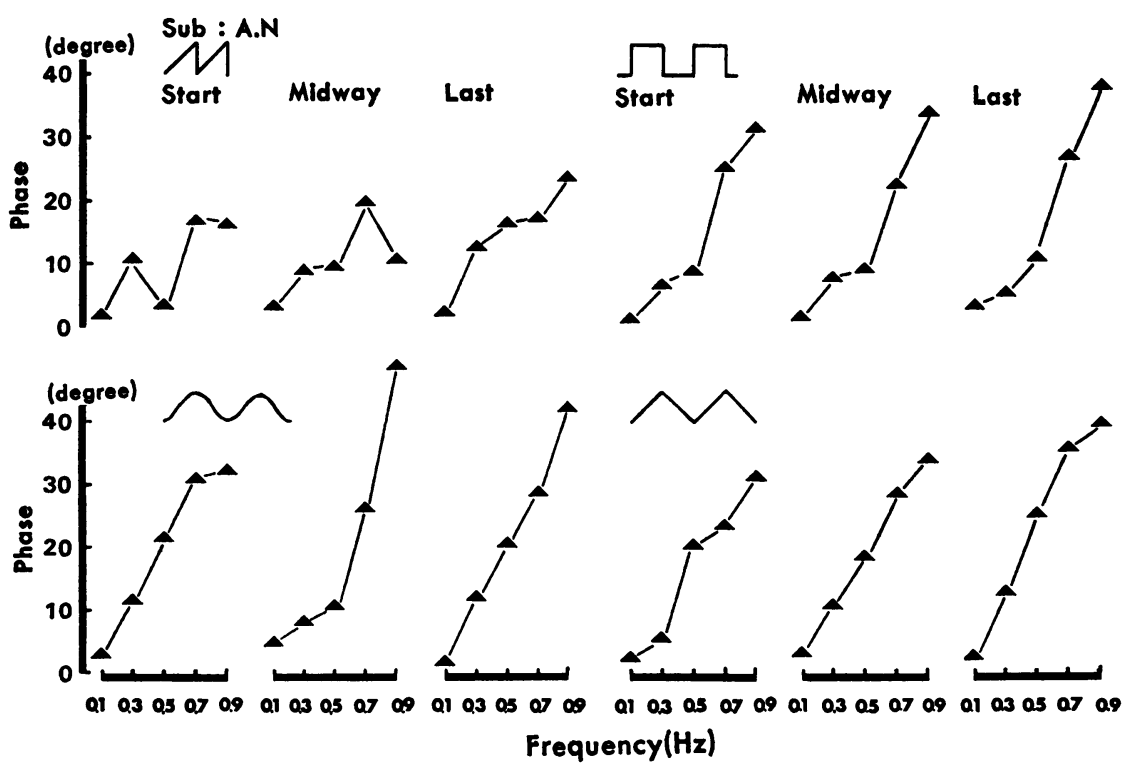

Fig. 7 Changes of phase in the case of pursuit movement

が，運動開始㨁後とオールアウト间前の㠹期間で は，両者の振幅の差はほとんどみられなかっ た。

\section{(3) 正弦波心答}

各周波数共に，運動開始直後で追従運動の振幅 が大きくなり，0.1，0.5,0.7 Hzでは，時間と其 に振幅比が 0 となり，0.3，0.5 Hz では，目標波 形と追従波形との問の統計的な有意な差はみられ なかった。

\section{(4) 三角波応答}

各周波数其に通動開始直後に追従进動の振幅が 小さくなるが，時間と共に目標値に近ずきオール アウト直前では 0 になり両者が一致している。

3）追従持続運動の位相おくれ……応答の速さ について

第 7 困は，目䌘波形と追従運動との位相のおく れをまとめたもので，横呻に凨波数をプロット し，縦軸におくれ量をプロットした。位相おくれ の算出には，晾记 2）の追従持続筋力の闰確性算: 出時間之同一時の追従おくれ留を测定して角度 （1 周期を $360^{\circ}$ として）で表示したものである。

(1) のとぎり波応答

$0.1 \mathrm{~Hz}$ のおくれ量は，連動開始㨁後 0 を示し以 後あほとんど変化がみられないが, $0.3 ， 0.5 ， 0.7$ $0.9 \mathrm{~Hz}$ では，運動時間之共におくれ量の增加が
みられる。

\section{(2) 矩形波心答}

$0.1 \mathrm{~Hz}$ のおくれ量は, 運動開始直後約 1 度を示 し, $0.3,0.5,0.7 \mathrm{~Hz}$ では, $0.1 \mathrm{~Hz}$ の10倍, 0.7 , $0.9 \mathrm{~Hz}$ では, 約 30 倍の増加がみられる。しかし運 動時間の持続増大とは無関係であった。

(3) 正弦波応答

$0.1 \mathrm{~Hz}$ では, 運動開始直後約 3 倍のおくれ量が みられるが以後有意な変化はみられなかった。 $0.3,0.5,0.7 \mathrm{~Hz}$ 共に運動開始直後より, 中期の おくれ量が少なく，終了直前で再び増加するパタ ーンがみられる。

(4) 三角波応答

$0.1 \mathrm{~Hz}$ では, 運動開始直後約 3 度のおくれ量が みられるが以後顕著な变化はみられなかった。 $0.3,0.5,0.7,0.9 \mathrm{~Hz}$ 共に運動持続時間の増大 之其におくれ量の比例的な增加がみられる。

オールアウト直前の 1 周期に扔ける目標波形と 追従運動量との位相おくれ量についてべクトル線 図を描いた。それが，第 8 四〜 9 図にまとめられ ている。こ机らは, オールアウト直前の一種の位 相扰くれ量を示し, 追従連動を評価し得る。X軸 に目標值，Y 軸に追徒運動量をプロットした。 $\mathrm{y}=\operatorname{ax}(\mathrm{a}=1)$ の線上即ち $45^{\circ}$ 線上が速応性が最適 で位相おく机が 0 であることを示している。のこ 

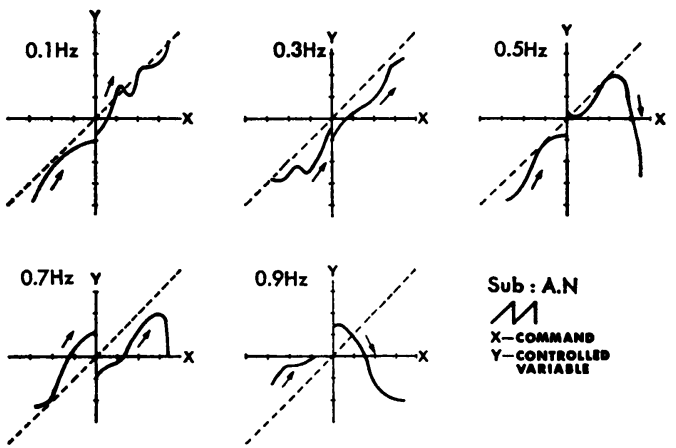

Fig. 8 Vector charts of the command and the controlled variable in the sawtooth waves
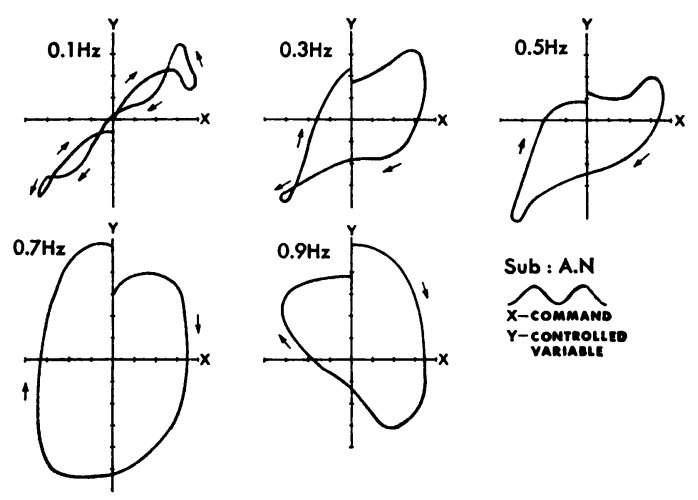

Fig. 9 Vector charts of the command and the controlled variable in the sinus waves

ぎり波，正弦波，三角波形共に，0.1，0.3，0.5 $\mathrm{Hz}$ では，顕著な位相おくれがみられないが, 0.7 , $0.9 \mathrm{~Hz}$ で湿著な位相打くれがみられ，0.7Hzで $45^{\circ}, 0.9 \mathrm{~Hz}$ で $90^{\circ}$ のずれがあらわれた。しかし,
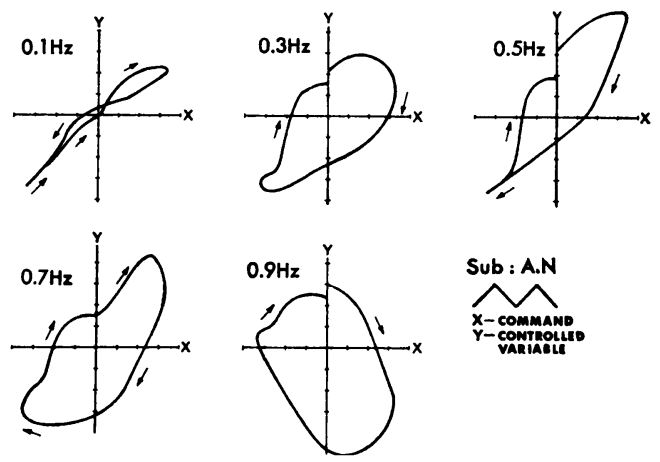

Fig. 10 Vector charts of the command and the controlled variable in the triangular waves

三角波形では，0.7Hzであほとんど変化がなく，

$0.9 \mathrm{~Hz}$ の早い応答になると急に位相おくれが大き くなり $90^{\circ}$ 前後にもなったが三角波形の追従運動 の良さを示すことになる。橋本, 朋石 ${ }^{3)}$ たちの自 動車のハンドル操作の追従と同じように, $1 \mathrm{~Hz}$ 近 くでの急激な位相おくれがみられた。これは，ほ とんど追従不可能に近いととをあらわしている。 人間の追従持続運動では，オールアウト近くにな ると，即ち困黄時期になると糺かい早い動きに刘 しての筋収縮, 弛緩のコントロールがスムーズに おこなわれなくなり上位中枢の命分は，on-off 的 な単純命令になり, 微妙なコントロールは, 脊䯣 レベル以下の反射的な動きにまかされた。これは

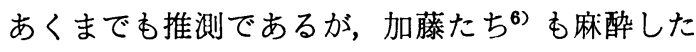
ヒトの手足の筋収縮実験によって証明しているよ うに，大脳皮質（新皮質）からの命令は，運動開 始時にはみられるがオールアウト時になるとみら

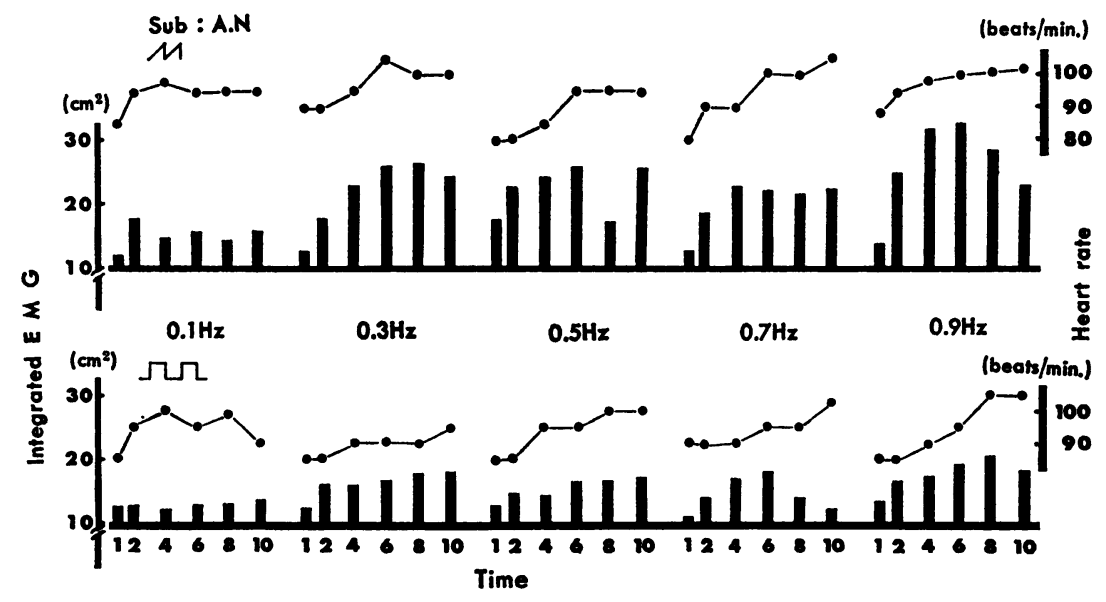

Fig. 11 Changes of EMG in the case of pursuit movement 


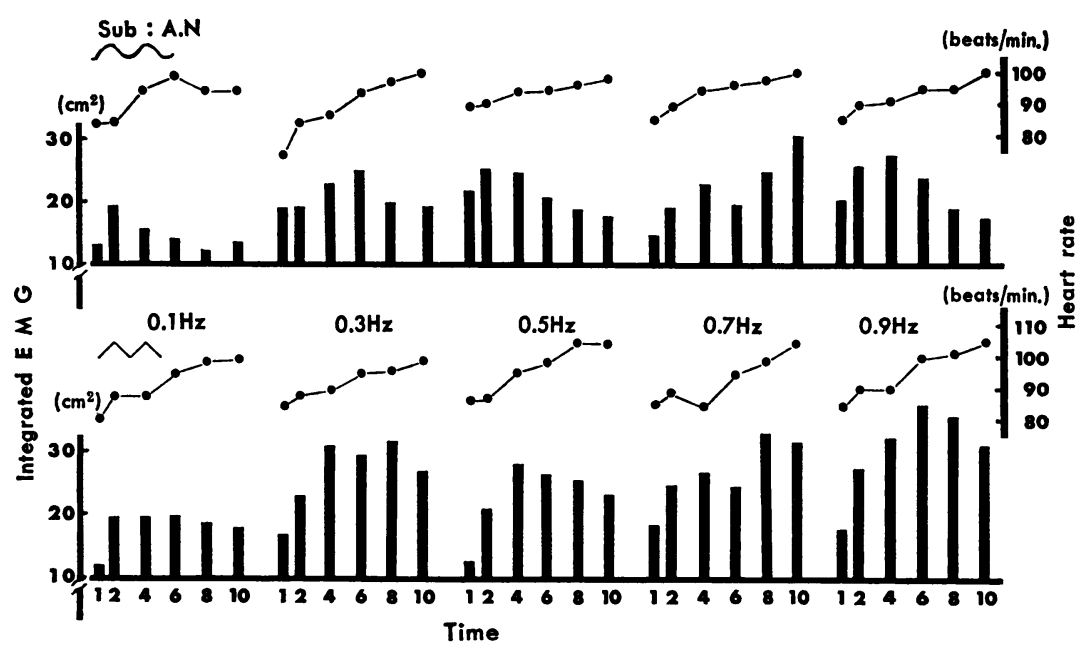

Fig. 12 Changes of EMG in the case of pursuit movement

れなくなる。そのためコントロールも低下する。

4）追従持続筋力発現中の筋放電量之心拍数の 変化について

追従運動の主働筋である大腿直筋の筋放電量と 心拍数についてまとめたものが第11図〜12図であ る。横軸は, 最大追徒運動時間を10として正規化 したものであり，緹軸には，筋放電量と心拍数を プロットした。

I ) 筋放電量の変化

(1) のこぎり波応答

$0.1 ， 0.3 ， 0.5,0.7 \mathrm{~Hz}$ では，運動時間の增大 之共に筋放電量は増加する傾向がみられ, $0.9 \mathrm{~Hz}$ では，運動の中期に最も多くそれ以後オールアウ ト時に近ずくにつれて減少するパターンがみられ た。

(2) 矩形波応答

$0.1,0.3,0.5 \mathrm{~Hz}$ で運動時間之共に筋放電量は 増加する傾向がみられ，0.7, $0.9 \mathrm{~Hz}$ では，のこ ぎり波形と同様に運動の中期より次第に減少する パターンがみられた。他の波形と比較すると, 各周波数共に約 $1 / 2$ の放電量しかみられなかっ た。

(3) 正弦波応签

$0.1,0.3,0.5,0.9 \mathrm{~Hz}$ では，運動の中期より 放電量の減少がみられ， $0.7 \mathrm{~Hz}$ のみ運動時間と共 に増加するパターンがみられた。

(4) 三角波応答

$0.1 \mathrm{~Hz}$ では，運動時間との 有意な差はみられ
ず, $0.3,0.5,0.7,0.9 \mathrm{~Hz}$ では, 時間之共に次 第に增加するが, 中期以後再び減少するパターン がみられた。他の波形と比較して, 各周波数とも にわずかに多くの放電量がみられた。筋放電量と 追従能力には, 有意な差がみられなかった。又拈 抗筋である大腿二頭筋の放電量は, ほとんごみら れず，拈抗筋としての働らきは，なかったよう だ。

II ）心拍数の変化

各波形, 各周波数共に心拍数は, 運動時間に比 例して増加する様相があり, 追彷運動開始後の増 加量は, 約20パルスで, オールアウト時には, 最 高心拍数 100 であった。運動量としても軽いもの で, 各波形, 各周波数間の有意差はなかった。

\section{4. 考察}

1）追従持続筋力の成績について

遅い追従運動, 即ち周波数が小さい場合では, 運動中期で調節成績が向上し，オールアウト直前 で再び低下するのは, 中枢からの命令と筋肉の応 答が目標波形に馿れ，波形を予測することのでき るフィードホワードの働きと考えられる。オール アウト時の反応については, 筋肉の疲労によって コントロールが十分におてなわれない現象と考え られる。早い追從運動, 即ち周波数が大きい場合 は，時間と共に調節成績が比例的に低下する。これ は，急激に，加早い張力変化に対する追従の困 難性を示し，人間の脚伸展に拈ける追従調節運動 
の限界を知る資料となるであろう。換言すると, $0.5 \mathrm{~Hz}$ が追従持続運動の限界とも考えられ, 制御 理論的な立場から言うと “臨界值”が示されたと 考えられる。

2）追従持続筋力の正確性の変化

他の波形に比較して, 特にのてぎり波形の追從 運動の振幅が小さい。これは, 目標波形が上限に到 達すると急激に下降するためにその低下波形を早 く追従するには, 追従動作を途中で止めなければ ならない。このために振幅は小さく，追従のおく れ現象も加味されたものである。矩形波でも振幅 此が小さいのは, 上限である筋力值の一定保持の 不安定性に起因すると考えられる。特にオールア ウト直前で, 早い追従運動の成績が良いのは, 筋 感覚のみによるコントロールが安定し, 他の無用 な感覚が阻止され, 追従のフィードホワードが働 いたものと考えられる。正弦波では，他の波形之 異なり振幅比が大きい，乙れは，周期的に筋力値 が変化するために, 波形の上限で切り換えがスム 一ズにおこなわれないため, ゆきすぎの現象, 即 ちオーバシュートがあらわれたと考えられる。三 角波形でのオールアウト直前の各周波数での成績 が良いのは, 一定速度に筋力值が上昇, 下降変化 するための筋感覚的な刟れとコンスタント・スピ 一ドの調節が中枢部においておこなわれたととを 物語っている。人間の運動調節は, 変位の 1 次微 分が限度で 2 次微分となると, 即ち加速度的な現 象への追従は困難である。三角波形は, 一種のラ ンプ入力と考えられ一種のプラス, マイナスの程 分的な追彷要素を含んでいる。

3）筋放電量，心拍数からみた生体変化

矩形波形の追従運動が他の波形の場合と比較し て約 $1 / 2$ の放電量を示している。てれは, 筋力の 発揮状態, 即ち大腿二頭筋の収縮状態が他の波形 と異なり一定負荷の持続保持の場合之常に変化す る負荷の保持の場合之の筋力発揮上の差があらわ れたものと考えられる。一度収縮し一定の筋放電 量を発揮した筋肉がさらに収縮し放電量を増加さ せることは筋生理学上からいって困難な課程であ る。しかし一定の筋力を保持するために一定の筋 放電を持続的に発揮するととは谷易な課程であ る。後者には, 特に疲労の問題が残るだけだが, 前者には, 篎放電量の調節が残されている。又,
「一定の大きさの力を最大時間維持したとき, EMGの大きさが時間と共に増加する」黒田たち7 の報告と同じように, 矩形波の遅い応答 $(0.1$, $0.3,0.5 \mathrm{~Hz}$ ) では, 時間と共に增加する傾向が みられた。大腿直筋の拮抗筋である大腿二頭筋の 筋放電量がみられないのは等尺性収縮の脚伸展運 動では拮抗筋の抑制的な働きは表面にあらわれな い屯の之考えられる。さらに筋放電間隔と周波数 の問題は, 今後追従運動の成績と関連して検討し なりればならない。

心拍数の変化については, 各波形, 各周波数間 に有意な差はなく, 運動持続時間の増加と共に比 例的に増加するパターンがみられるのみで，全身 の循環的, 精神的な影響はすべて近似的と考えら れる。最高心拍数が 100 前後であるので持続追従 運動は, あまり全身的な強い運動ではないよう だ。

4）持続追従運動における制御理論的な総合評 価

各波形のパターンからみた制御成績, 正確性, 速 応性, 安定性を総合的にあらわしたものが表 3 で あり，表中の○は最む良く(上)，○は普通で(中)， ○はあまり良くない(下)，段階のできばえとして 区分した。

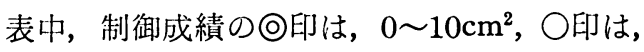
$11 \sim 50 \mathrm{~cm}^{2}$, ○印は, $51 \mathrm{~cm}^{2}$ 以下の 目標值と追従 運動との偏差量を示す。正確性の ○印は, 0 〜 $0.4 \mathrm{db}, \bigcirc$ 印は， $\pm 0.5 \sim \pm 0.9 \mathrm{db} ， ○$ 印は $\pm 1 \mathrm{db}$ 以上の目標值と追従運動との振幅差を示す。速応 性の○印は, 0〜10degree, ○印は 11〜20degree, ○印は 21degree 以上の位相括くれ量を示す。安 定性については, 振動して平衡するもの, 振動し ないで平衡するものの両者 ${ }^{12)}$ から， ○印は，0〜 $30 \mathrm{~cm}^{2}$, ○印は, $0 \sim 100 \mathrm{~cm}^{2}$, ○印は, $101 \mathrm{~cm}^{2}$ 以 上の偏差量の幅を基準とした。

(1) のこぎり波応答

各周波数共に, 制御成績, 速応性, 安定性の項 目で他の波形よりすぐれた調節がみられるが, 正 確性では, $0.5 \mathrm{~Hz}$ 以上の速い周波数で悪い調節之 なっている。しかし，全般的にみてての波形の調 節が最も良い結果を示す。てれは，生体並びにモ デルシュミュレーションによる等尺性収縮の筋力 の発胃パターンと類似)した波形であるととに起 
Table 3 Comparison of per formance, accuracy, quickness, and stability on the pursuit movement

\begin{tabular}{|c|c|c|c|c|c|}
\hline $\mathrm{Hz}$ & Waves & Performance & Accuracy & Quickness & Stability \\
\hline 0.1 & $\begin{array}{l}\text { Sawtooth } \\
\text { Rectangle } \\
\text { Sinus } \\
\text { Triangle }\end{array}$ & $\begin{array}{l}\text { () } \\
\text { ○) } \\
\text { ○) } \\
\text { ○ }\end{array}$ & $\begin{array}{l}(0) \\
0 \\
\bigcirc \\
0\end{array}$ & $\begin{array}{l}\text { (?) } \\
\text { (?) } \\
\text { () } \\
\text { (?) }\end{array}$ & $\begin{array}{l}\text { () } \\
\text { ○) } \\
0 \\
0\end{array}$ \\
\hline 0.3 & $\begin{array}{l}\text { Sawtooth } \\
\text { Rectangle } \\
\text { Sinus } \\
\text { Triangle }\end{array}$ & $\begin{array}{l}\text { (?) } \\
\text { () } \\
\text { () } \\
\text { (?) }\end{array}$ & $\begin{array}{l}\text { ○ } \\
0 \\
0 \\
0\end{array}$ & $\begin{array}{l}\text { (?) } \\
\text { ○) } \\
0 \\
0\end{array}$ & $\begin{array}{l}0 \\
\bigcirc \\
0 \\
0\end{array}$ \\
\hline 0.5 & $\begin{array}{l}\text { Sawtooth } \\
\text { Rectangle } \\
\text { Sinus } \\
\text { Triangle }\end{array}$ & $\begin{array}{l}\text { (?) } \\
\text { () } \\
0 \\
0\end{array}$ & $\begin{array}{l}0 \\
0 \\
0 \\
0\end{array}$ & $\begin{array}{l}0 \\
0 \\
0 \\
0\end{array}$ & $\begin{array}{l}\text { () } \\
\text { (?) } \\
\text { ○) } \\
0\end{array}$ \\
\hline 0.7 & $\begin{array}{l}\text { Sawtooth } \\
\text { Rectangle } \\
\text { Sinus } \\
\text { Triangle }\end{array}$ & $\begin{array}{l}0 \\
0 \\
0 \\
0\end{array}$ & $\begin{array}{l}0 \\
\text { (?) } \\
\text { () } \\
\text { () }\end{array}$ & $\begin{array}{l}0 \\
0 \\
0 \\
0\end{array}$ & $\begin{array}{l}0 \\
0 \\
0 \\
0\end{array}$ \\
\hline 0.9 & $\begin{array}{l}\text { Sawtooth } \\
\text { Rectangle } \\
\text { Sinus } \\
\text { Triangle }\end{array}$ & $\begin{array}{l}0 \\
0 \\
0 \\
0\end{array}$ & $\begin{array}{l}\text { ○ } \\
\text { () } \\
\text { () } \\
\text { (?) }\end{array}$ & $\begin{array}{l}0 \\
0 \\
0 \\
0\end{array}$ & $\begin{array}{l}0 \\
0 \\
0 \\
0\end{array}$ \\
\hline
\end{tabular}

() : Best

: Bad

因する。

(2) 矩形波応答

$0.5 \mathrm{~Hz}$ までは, 制御成績, 速応性, 安定性共に 良い調節状態 がみられるが，正確性では，逆に $0.7 \mathrm{~Hz}$ と $0.9 \mathrm{~Hz}$ が良い調節を示している。との ような on-off 的な追従は，かなり易しい部類早に 入るが, 筋力の上限や下限での急激な停止が必要 で,オフセットやオーバーシュートの状態があら われて，全般的な追従成績としては悪くなる。

(3) 正弦波芯答

$0.5 \mathrm{~Hz}$ までは, 各項目共に良い調節状態がみら れるが, $0.7 \mathrm{~Hz}$ から急激に制御成緽と安定性が悪 くなっている。筋長の変化は，かなりなめらかな 周期的変化 ${ }^{2)}$ をるものでての正弦波に類似して いるが，筋力の持続追従運動は，正弦波応答之無 関係であった。即ち, 筋力は, 筋長の变化とは相 反するあのである。

\section{(4) 三角波応答}

$0.3 \mathrm{~Hz}$ までは，各項目其に，良い调㧕状態がみ られるが， $0.5 \mathrm{~Hz}$ から速応性，安定性共に急激に
悪くなり，追従のむずかしさが顕著にあられてい る。この波形は，上記ののこぎり波と正弦波の総 合したものに類似しているが筋力の追従成績は, 正弦波に近い状態であった。

5）システム論的な解析

本研究は，一般的な実験データの報告に終った けれどあ，このような生体の調節系の運動の解析 には，工学的な手法を利用すると便利である。そ のために，運動の具体的な内容をブロック線図 （第 1 図参照）であらわし，数理的な定量分析に かけることが大切である。しかし，今回は，数理 的な計算はできなかったが，今後，電子計算機等 によってそのデータを報告したい。

\section{5. 要約}

1）運動のバイオメカニックス的な解析の第一 少として脚の持続追従運動をとりあげた。

2）各波形の持続追従運動では, $0.5 \mathrm{~Hz}$ の周波 数が限界で, それ以後の大きい周波数では追従不 能に近づく。 
3）のとぎり波，矩形波，正弦波，三角波の 4 波形での持続追従運動を比較すると,のこぎり波 の場合が最も秀れた成績を得た。

4）追従運動を持続させてオールアウトに近づ けば, 追従成績, 正確性, 速応性, 安定性の面で 悪くなる様相であった。

5）位相の面からいっても，特別にのてぎり波 の追従運動が秀れている。例えば, ベクトル線図 をみると，目標波形と追徒波形のずれは，他の波 形に比較して小さく，0.7 Hz まで正確な追従曲線 を描いている。

6）追従運動における生体反応は，心拍数から みると軽い運動で, 目標波形の繰り返しリズムに よる心拍数の増減はみられなかった。筋放電量 は，増加し持続時間と比例的な関係を示した。ま た目標波形のリズムと生体反応のリズムは一致し なかった。

（受付 昭和 49 年 10 月 28 日）

\section{引用文献}

1）井口雅一 (1972) 人間一機械系 2 版, 人間の 制御動作，共立出版，東京，15-44

2）藤森聞一（1966）生理学大系V初版, 強縮の 力学, 医学专院, 東京, 100-105

3）橋本 寛, 明石 一-(1970) 人間機械系にお ける人間の制御能力の限界, 人間工学, 6-6, 259-266
4）畠山一平, 三枝木泰文, 永田 晨（1971）筋 固有反射系の自動制御理論的解析, 計測自動制 御学会論文集, 8-4,395-396

5) Karl, U., Smith, Harvey, Sussman (1970) Principles of skill acquisition, 2nd Cybernetic Theory and Analysis of Motor Learning and Memory. Academic Press Chicago. 103-139

6) 加藤一郎（1971）続人間の手足の制御, 初版, 機能刺激, 学献社, 東京, 433-484

7）黒田英三, V. Klissouras, J.H.Milsum (1972) バイオメカニズム，初版，随意運動における筋 電位の定量的解析および疲労の影響, 東京大学 出版会, 東京, 47-55

8）増山英太郎（1967） 人間のトラッキング動作 におりる過渡特性と周波数特性, 人間工学, 3$4,327-334$

9）永田 昆（1970）調節運動の自動制御理論的 研究, 東京都立大学体育学研究, $3,39-50$

10）永田 晨 (1972) 運動軌跡のミニコンピュタ 一によるプログラム化とその時定数からみた追 跡能力の評価, 東京都立大学体育学研究, 4 , 61-71

11）椹木義一，添田 喬（1972） わかる自動制御 11版, 周波数応答, 日新出版, 東京, 90-106

12）上滝致孝 (1971) 制御工学を学ぶ人のために, 初版, 伝達要素の動特性, オーム社, 東京, 15 $-21$ 